\title{
Cetacean records from Tristan da Cunha, South Atlantic
}

\author{
PETER B. BEST ${ }^{1}$, JAMES P. GLASS ${ }^{2}$, PETER G. RYAN ${ }^{3}$ AND MEREL L. DALEBOUT ${ }^{4}$ \\ ${ }^{1}$ Mammal Research Institute, University of Pretoria, South Africa, ${ }^{2}$ Department of Agriculture and Natural Resources, Tristan da \\ Cunha, South Atlantic, ${ }^{3}$ Percy FitzPatrick Institute, University of Cape Town, Rondebosch 7701, South Africa, ${ }^{4}$ School of Biological, \\ Earth and Environmental Sciences, University of New South Wales, Sydney, New South Wales, Australia
}

\begin{abstract}
The cetacean fauna at the Tristan da Cunha archipelago has been assessed from ship-based, aerial and land-based observations from 1983-2000, from strandings on Tristan da Cunha and Inaccessible Island between 1983 and 1995, and from whaling catch data from 1934-1967. Five species (Eubalaena australis, Megaptera novaeangliae, Tasmacetus shepherdi, Globicephala melas and Orcinus orca) have been sighted within the territorial waters of the archipelago, eight species (Balaenoptera physalus, B. borealis, B. acutorostrata/bonaerensis, Physeter macrocephalus, Mesoplodon mirus, M. bowdoini, Delphinus sp. and Lissodelphis peronii) have been seen or taken within 200 nautical miles (360 $\mathrm{km}$ ) of the group or have been found stranded on its shores, while another two species (Caperea marginata and Lagenorhynchus obscurus) have been recorded close enough to be considered likely to occur within 200 nautical miles. The records of Mesoplodon mirus and M. bowdoini represent significant extensions to their known distribution. Apart from its possible importance as a mid-oceanic nursery area for southern right whales, the waters of the Tristan Archipelago seem to be a concentration area for T. shepherdi, one of the least-known of the world's cetaceans.
\end{abstract}

Keywords: cetacean records, Tristan da Cunha, South Atlantic

Submitted 28 March 2008; accepted 1 April 2009

\section{INTRDDUCTION}

The three main islands that form the Tristan Archipelago are in one of the most remote regions of the South Atlantic, being 1500 nautical miles from the nearest continent. Tristan da Cunha itself, centred at $37^{\circ} 06^{\prime} \mathrm{S} 12^{\circ} 17^{\prime} \mathrm{W}$, is the largest island ( $\sim 12 \mathrm{~km}$ in diameter), followed by Inaccessible $(4.5-5.5 \mathrm{~km}$ in diameter) about 20 nautical miles to the southwest and Nightingale ( $2 \mathrm{~km}$ in diameter) about 10 nautical miles to the south-east of Inaccessible (Figure 1). Tristan has been permanently inhabited since the early 19th Century, but there is little published information on the cetacean fauna to be found round the shores of the archipelago.

At $37^{\circ}-37^{\circ} 30^{\prime} \mathrm{S}$, the Tristan group lies in the vicinity of the Sub-Tropical Convergence (STC). With sea surface temperatures ranging seasonally between 15 and $19^{\circ} \mathrm{C}$ in summer and $13-15^{\circ} \mathrm{C}$ in winter, and surface salinities more typical of subtropical than subantarctic water, the archipelago is situated close to the northern edge of the STC, although still under its influence through cast-off eddies, filaments and other protrusions throughout the year. Gough Island, at $40^{\circ} 19^{\prime} \mathrm{S} 9^{\circ} 56^{\prime} \mathrm{W}$, is only some $380 \mathrm{~km}$ south-south-east of Tristan da Cunha, but consistently has sea surface temperatures some $3^{\circ} \mathrm{C}$ cooler, and is considered to lie closer to the southern edge of the STC (Andrew et al., 1995). Its cetacean fauna is not considered here

In this paper we report on records of cetaceans recently sighted in the waters round the Tristan Archipelago (1983-2000) or

Corresponding author:

P.B. Best

Email: pbest@iziko.org.za stranded on its shores (1983-1995), and include a review of published material and commercial catches from the region.

\section{MATERIALS AND METHODS}

As volcanic projections to the east of the mid-Atlantic Ridge, the Tristan islands are surrounded by water over $2000 \mathrm{~m}$ deep (Figure 1). The 'plateau' on which they lie is roughly defined by the contiguous 12 nautical mile territorial waters of all three islands, so this has been considered a biologically appropriate boundary to use when considering the cetacean fauna of the area. However, there are deep-water trenches between the islands, with water $>500 \mathrm{~m}$ deep between Inaccessible and Nightingale, and $>1000 \mathrm{~m}$ deep between these islands and the main island of Tristan. Tristan da Cunha itself is a relatively young island (200,000 years old), with its volcanic peak rising $2060 \mathrm{~m}$ above sea level. It is the only inhabited island in the group, with some 280 people living in the only settlement at the northern corner of the island. Marine erosion has resulted in extremely narrow beaches and steeply sloped coastal scarps (Crawford, 1982). Rockfalls and slumping are fairly regular, so inland routes are generally preferred when traversing the island. Being mid-oceanic there is also little tidal influence, with maximum tidal range being $<_{1} \mathrm{~m}$. Together with the strong oceanic swells these factors mean that the chances of a cetacean stranding being detected are low. The rugged terrain also complicates the process of retrieving any material from a stranding, and most cetaceans documented here had to be dissected on site and removed to the top of the beach, to be recovered later by sea or helicopter. 


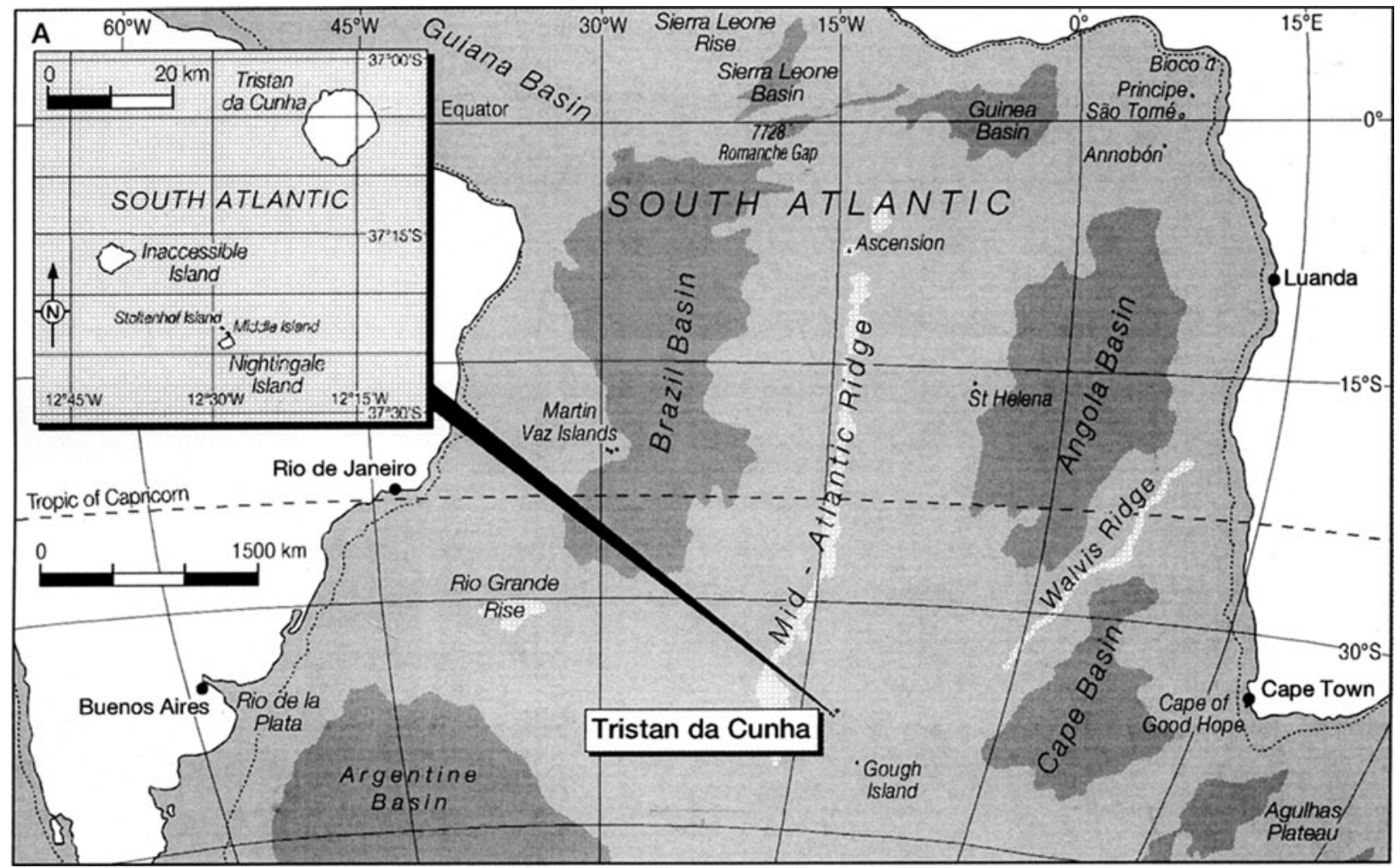

Fig. 1. Map of the Tristan da Cunha group and its position in the South Atlantic.

Apart from a rock lobster Jasus tristani fishery that operates round the archipelago, there is little regular shipping traffic in the vicinity of Tristan da Cunha, and scientific expeditions to the region have been few and far between. Dedicated cetacean sighting effort has therefore been extremely limited, and has been largely confined to visits by the South African Antarctic supply vessel MV 'SA Agulhas' in September or October 1983, 1985, 1986, 1987, 1988 and 1989 , when cetacean observers were placed onboard and on helicopters associated with the vessel.

Incidental sightings of right whales made from the rock lobster vessels operating from Tristan itself have been compiled for the years 1986-1991. Records were kept of the dates of all fishing days, the coastal area covered and the locality and number of whales seen. Incidental sightings from the shore, including sightings by a shore-based observer at Tristan da Cunha between October 1989 and October 1990, have also been included where the species identification is considered reliable (i.e. accompanied by an adequate description or image, or submitted by an experienced observer). Incidental observations made by one of us (P.G.R.) during visits to the archipelago in September-October 1987 and October 1988 (3-weekly periods), from October 1989 to March 1990, October 1999 to February 2000, and in 4-weekly visits in November-December 2004 and OctoberNovember 2007 have also been incorporated: much of this time was spent on Inaccessible Island.

The positions of 1040 large whales taken by Antarctic whaling expeditions in the square $35-39^{\circ} 59^{\prime} \mathrm{S} 10-14^{\circ} 59^{\prime} \mathrm{W}$ (henceforward known as the 'Tristan Square') have been extracted from the International Whaling Commission (IWC) database. These catches covered the period 1934-1967, but most (97\%) were from 1961 onwards: they originated mainly from the months of November/December and February/April (coinciding with the beginning and end of the Antarctic whaling season respectively, as expeditions transited to and from the Antarctic).

\section{RESULTS}

\section{Whalebone whales Suborder MYSTICETI}

\section{Family Balaenidae}

\section{SOUTHERN RIGHT WHALE EUBALAENA}

AUSTRALIS (DESMOULINS, 1822)

The historical importance of Tristan da Cunha as a concentration area for southern right whales was reviewed by Best (1988). The archipelago fell within a larger geographical region known to 19 th Century whalers as the Tristan ground, whose geographical limits have been described as roughly between 28 and $42^{\circ} \mathrm{S}$, and from o to $20^{\circ} \mathrm{W}$ (Clark, 1887). Plots of the positions of whale ships on days on which one or more right whales were taken, however, seem to indicate some discrimination between the Pigeon Ground to the west of Tristan $\left(31-39^{\circ} \mathrm{S} 16-28^{\circ} \mathrm{W}\right)$, the Tristan Ground itself (not specified but roughly $33-39^{\circ} \mathrm{S} 9-14^{\circ} \mathrm{W}$ ), and a band of catches between 30 and $39^{\circ} \mathrm{S}$ and east of $8^{\circ} \mathrm{W}$ almost as far as the African coast (Townsend, 1935).

Illegal 2oth Century whaling by Soviet expeditions also indicates a concentration of catches round Tristan da Cunha $\left(35-41^{\circ} \mathrm{S} 7-19^{\circ} \mathrm{W}\right)$ and scattered takes in a band between 36 and $38^{\circ} \mathrm{S}$ extending from Tristan towards the African continent (Tormosov et al., 1998). Individual catch records 
for 329 right whales from the Tristan Square in the IWC database are mostly grouped tightly around the archipelago but some extend in a line between 37 and $38^{\circ} \mathrm{S}$ to the east (Figure 2).

Of the 75 sightings of 116 right whales recorded at the Tristan Archipelago between 1983 and 1991, all but one were from the main island, the exception being a sighting made off Inaccessible Island. Although this may largely reflect the fact that Nightingale and Inaccessible Islands are not permanently inhabited, all 14 flights made round the archipelago by helicopter failed to locate a right whale at any island other than Tristan itself. Only three of the sightings occurred outside the period July-November. If those seen on the helicopter surveys are excluded (because the surveys were restricted to the period SeptemberNovember), the peak months were September (40\%) and October (33\%). There is a similar pattern to the numbers of whales seen (99), with $48 \%$ being in September and $29 \%$ in October (Figure 3).

In the 1950s, before the episode of illegal exploitation by Soviet whalers, the whales were said to arrive in July, reach a peak in October and leave in December (Elliott, 1953), which is virtually identical to the pattern shown in Figure 3.

Twenty of the sightings (27\%) involved cow-calf pairs; they are probably under-represented in the sample, given the difficulty of detecting the presence of a calf in sightings from the shore. The distribution of sightings round the island is clearly influenced by the amount of sighting effort, with $39(52 \%)$ from the vicinity of the Settlement or the Potato Patches to the west, the areas of greatest human habitation or visitation (Figure 4). However, the majority (13/19, or $68 \%$ ) of sightings of cow-calf pairs occurred in the uninhabited, south-east quadrant of the island between Sandy Point and Stonyhill Point: this region in fact was characterized by a much higher ratio of cow-calf pairs in sightings, 13/22, compared to $5 / 39$ in the vicinity of the Settlement $\left(\chi^{2}=\right.$ 12.34, $P<0.001)$. This segregation of cow-calf pairs is typical of winter nursery areas for southern right whales elsewhere, such as in southern African coastal waters (Best et al., 2003).

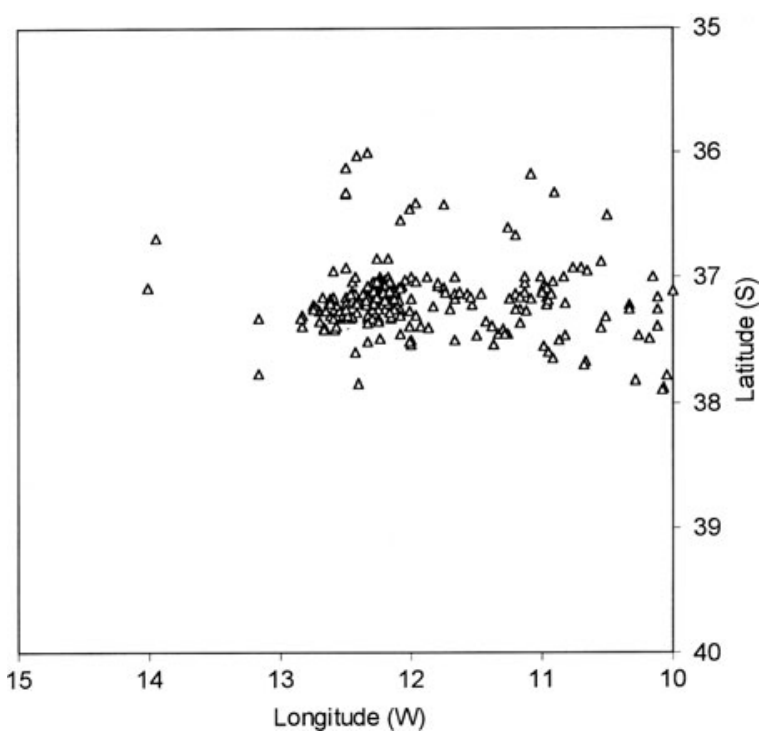

Fig. 2. Positions of right whale catches round Tristan da Cunha, 1962-1966 (archipelago obscured by density of plots)

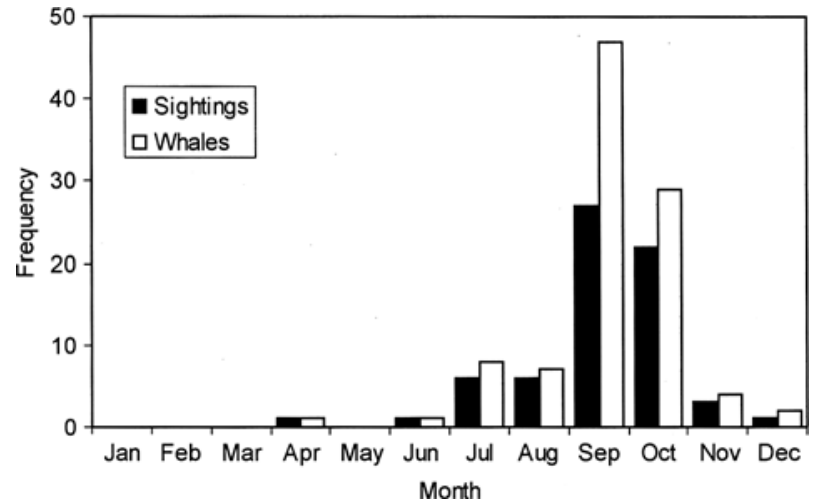

Fig. 3. Monthly frequency of southern right whale sightings at the Tristan da Cunha Archipelago, 1983-1991 (excluding those seen on helicopter surveys).

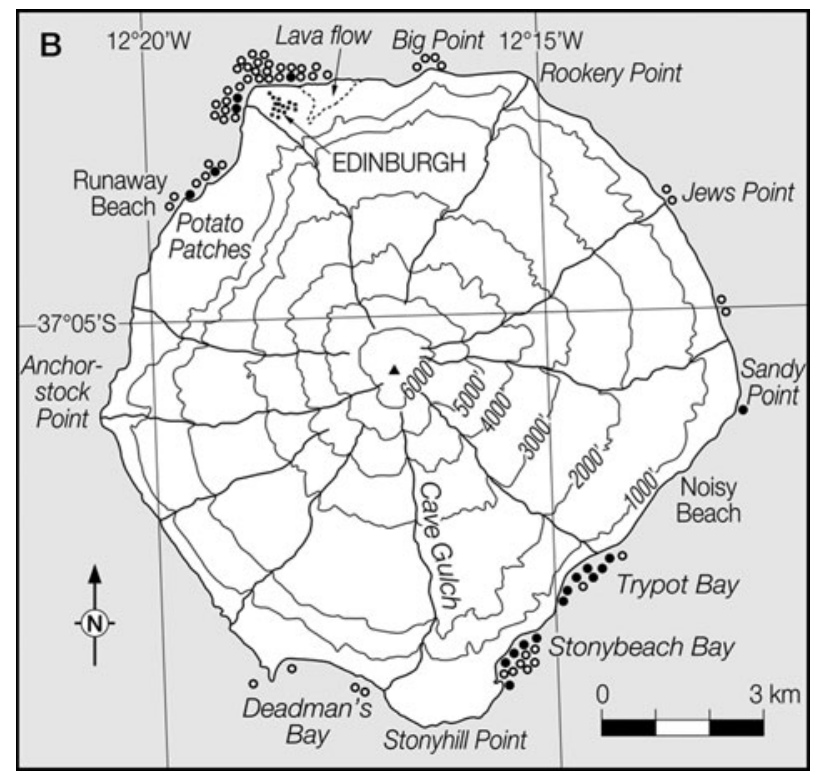

Fig. 4. Distribution of right whale sightings round Tristan da Cunha (open circles, whales without calves; closed circles, cow-calf pairs).

\section{Family Neobalaenidae}

PYGMY RIGHT WHALE CAPEREA MARGINATA

(GRAY, 1846)

On 30 November 1970, a $6.35 \mathrm{~m}$ pygmy right whale was taken in deep offshore waters by a Soviet whaling expedition at $35^{\circ} \mathrm{S}$ $8^{\circ} \mathrm{W}$ (Budylenko et al., 1973), or $\sim 450 \mathrm{~km}$ north-east of Tristan da Cunha. There are no records for the species closer to the islands, despite the island group being within the known distribution of the species.

\section{Family Balaenopteridae}

HUMPBACK WHALE MEGAPTERA NOVAEANGLIAE (BOROWSKI, 1781)

Humpback whales are occasional visitors to Tristan waters, mainly on migration (Bester \& Ryan, 2007). On 1 December 1965 , a $13.8 \mathrm{~m}$ female humpback whale was taken by a Soviet whaler at $37^{\circ} 25^{\prime} \mathrm{S} 12^{\circ} 33^{\prime} \mathrm{W}$, or about $40 \mathrm{~km}$ south-west of Tristan da Cunha. On 17 November 1985 one was seen 
from the air on the Tristan Plateau, at about $37^{\circ} 21.4^{\prime} \mathrm{S}$ $12^{\circ} 28.5^{\prime} \mathrm{W}$, or 2 nautical miles north of Nightingale Island. On 23 January 1990 two (one about two-thirds the length of the other) were seen from the shore, off Blenden Hall/West Point, Inaccessible Island.

FIN WHALE BALAENOPTERA PHYSALUS

(LINNAEUS, 1758)

According to Bester \& Ryan (2007), fin whales are fairly common round Tristan from October to December, often in loose groups of up to 5-10 animals. However, these are mainly seen $2-3$ days' sailing (or $\sim 400-600$ nautical miles) away from the islands, although they have occasionally been seen within a day's sailing $(\sim 200$ nautical miles). There are only four records of fin whales being taken in modern whaling in the Tristan Square (Figure 5). The closest to the archipelago was taken on 4 November 1962, at $37^{\circ} 05^{\prime} \mathrm{S}$ $10^{\circ} 18^{\prime} \mathrm{W}$ or about $175 \mathrm{~km}$ east of Tristan da Cunha.

SEI WHALE BALAENOPTERA BOREALIS LESSON, 1828 Although no recent sightings in the region have been attributed to this species, there are records of 58 sei whales taken in the Tristan Square by Antarctic whaling fleets. All were taken north of $38^{\circ} \mathrm{S}$ and mostly scattered to the east of the archipelago (Figure 5). Two sei whales were tagged with 'Discovery' marks at $36^{\circ} 22^{\prime} \mathrm{S} 12^{\circ} 48^{\prime} \mathrm{W}$ and one at $36^{\circ} 19^{\prime} \mathrm{S} 12^{\circ} 57^{\prime} \mathrm{W}$, or 94-105 km north-west of Tristan da Cunha, in November 1965. These were numbered stainless steel tubes fired into the body of the whale and so only recovered after the death of the animal. Two of these whales were killed and the marks recovered 2-3 months later, by which time they had moved south and west to latitudes of $44-46^{\circ} \mathrm{S}$, while the third was recovered almost a year later about $2700 \mathrm{~km}$ to the east of Tristan (Brown, 1977). These examples indicate the high mobility of the species (and of balaenopterid whales in general).

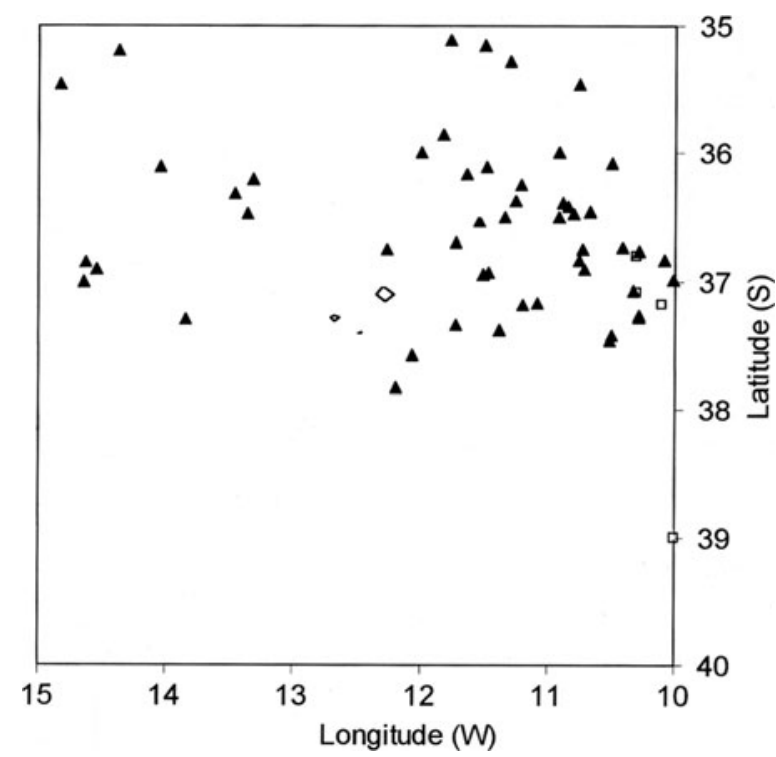

Fig. 5. Positions of sei whale (triangle) and fin whale (square) catches round Tristan da Cunha, 1962-1967.
ANTARCTIC MINKE WHALE BALAENOPTERA BONAERENSIS BURMEISTER, 1867, OR DWARF MINKE WHALE B. ACUTOROSTRATA UNID SUBSP.

These two taxa have only been recognized comparatively recently as two different species, although the taxonomic relationship between the dwarf minke whale and minke whales of the northern hemisphere is still uncertain. Antarctic and dwarf minke whales differ in size, morphometrics and coloration of the body and baleen, but distinguishing between them at sea requires a close approach and a good view of the animal's pigmentation pattern (Best, 2007).

Incidental reports of 'minke whales' around the Tristan archipelago have been received on a number of occasions, but few of these have been positively identified and there is the possibility that some are confused with other similar-sized cetaceans such as Shepherd's beaked whale T. shepherdi. Definite sightings of minke whales were made from MV 'SA Agulhas' on 7 October 1988, when two groups of 2 and 3 animals respectively were encountered at $36^{\circ} 26^{\prime} \mathrm{S} 8^{\circ} 28^{\prime} \mathrm{W}$, or $350 \mathrm{~km}$ east-north-east of Tristan da Cunha. Although the species in both cases was recorded as $B$. acutorostrata, no other information was provided from which it could be deduced whether the animals were actually Antarctic or dwarf minke whales.

\section{Toothed whales Suborder ODONTOCETI}

\section{Family Physeteridae}

\section{SPERM WHALE PHYSETER MACROCEPHALUS}

LINNAEUS, 1758

Bester \& Ryan (2007) note that sperm whales are 'fairly common' in Tristan waters. A sperm whale was found stranded on Inaccessible Island by the Denstone College Expedition in 1982, and remains (including teeth) were still present in October 1987 (P.G.R., personal observation). 19th Century whalers took sperm as well as right whales on the Tristan ground, mainly between October and January (Townsend, 1935). There are records of 648 sperm whales being taken by modern whaling in the Tristan Square, mostly from 1962 to 1967 . For 219 of these records there is no information on length or sex, but the remaining catches comprised 243 males and 186 females. Females were only taken north of $37^{\circ} 30^{\prime} \mathrm{S}$, and mostly to the west of the archipelago, with small males ( $11 \mathrm{~m}$ or less in length) being similarly distributed, whereas males larger than $11 \mathrm{~m}$ were distributed more widely, particularly farther south and east (Figure 6).

The closest recent sighting appears to be 3 whales seen from MV 'SA Agulhas' on 6 November 1985, in $36^{\circ} 24^{\prime}$ S $13^{\circ} 04^{\prime} \mathrm{W}$, or about $105 \mathrm{~km}$ north-west from the archipelago.

\section{Family Ziphiidae}

\section{SHEPHERD'S BEAKED WHALE TASMACETUS}

SHEPHERDI OLIVER, 1937

On 15 April 1983, two dead beaked whales were found on the beach south of Anchorstock Point, Tristan da Cunha, by members of the Denstone College Expedition to Tristan da Cunha. Both were measured (Table 1) and one was photographed (Figure 7). Both were described as 'bulls'. Although no skeletal or other material was collected, the full set of 


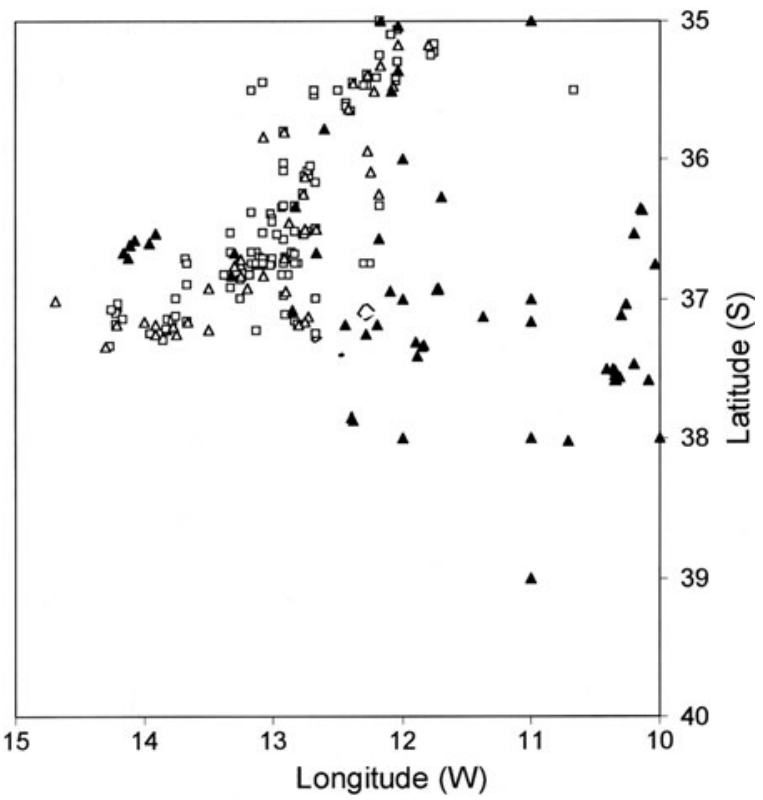

Fig. 6. Catches of small male (open triangle), other male (solid triangle) and female (open square) sperm whales off Tristan da Cunha, 1934-1967.

Table 1. External measurements of Shepherd's beaked whales found stranded on Tristan da Cunha in April 1983.

\begin{tabular}{llc}
\hline Measurement & No. 1 & No. 2 \\
\hline Length & $7.35 \mathrm{~m}$ & $7 \mathrm{~m}$ \\
Jaw length (lower longer) & $0.6 \mathrm{~m}$ & $0.55 \mathrm{~m}$ \\
Length front flippers & $0.5 \mathrm{~m}$ & $0.5 \mathrm{~m}$ \\
Height of back fin & $0.3 \mathrm{~m}$ & $0.3 \mathrm{~m}$ \\
Number of teeth & Approximately 48 in two rows \\
& \multicolumn{2}{c}{ on each jaw, total 96 } \\
Shape and size of teeth & All pointed 'canine' teeth, \\
& \multicolumn{2}{c}{ many curved to the point, } \\
& and many near jaw tip worn \\
& \multicolumn{2}{c}{ down. 2.5-3.5 cm including } \\
& root \\
\hline
\end{tabular}

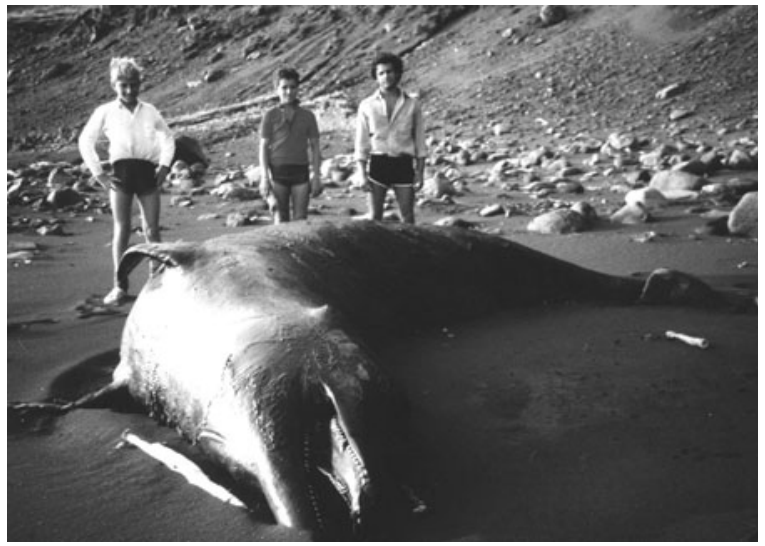

Fig. 7. One of two Shepherd's beaked whales stranded on Tristan da Cunha in 1983 (photograph M.K. Swales).

upper and lower teeth visible in the photographs and noted in the description indicates that the animals must have been T. shepherdi. All other beaked whale species have highly reduced dentition, with only $2-4$ teeth in the lower jaw and none in the upper (except M. grayi which may have varying numbers of small vestigial teeth set loosely in the gum tissue towards the back of the upper jaw; Best, 2007).

On 13 October 1984, a dead beaked whale was found at Deadman's Beach, Stony Hill Point, Tristan da Cunha. It was photographed from the air on 17 November 1984 and visited (by J.P.G.) on 13 March 1985, when it was measured as $6.7 \mathrm{~m}(22 \mathrm{ft})$ in length and the skeleton was prepared and left on the beach for later collection. From the description and some teeth collected the animal was identified as T. shepherdi. The sex was not determined. The specimen was retrieved in October 1985 and accessioned in the South African Museum (ZM 40484).

On 9 December 1987, two T. shepherdi were found dead about $50 \mathrm{~m}$ apart at Runaway Beach, Tristan da Cunha. The larger animal (estimated as $20-24 \mathrm{ft}$, or $6.1-7.3 \mathrm{~m}$, in length) smelt rotten and was thought to have been possibly floating around at sea for some time before stranding. It was apparently washed off the island again before any skeletal material could be collected, but some photographs were taken (by J.P.G.) and the post-cranial material later presented to the South African Museum (ZM 41113) seems to include elements from more than one individual. The smaller whale (estimated at $10-14 \mathrm{ft}$, or $3-4.3 \mathrm{~m}$, in length) was judged to be less decomposed than the larger, and the lower jaw was broken. Photographs were taken and the skull and some of the post-cranial skeleton collected and accessioned at the South African Museum (ZM 41116 and 41113 respectively).

In about October 1995 a large beaked whale was found dead at Noisy Beach, Tristan da Cunha. It was identified as T. shepherdi, cut up and hauled above the high watermark (by J.P.G.). A year later the skeleton was collected and accessioned into the South African Museum (ZM 41613). Details of the specimen's provenance are unfortunately vague because the original data sheets were lost.

On 17 November 1985, two sightings of beaked whales were made from the air on the Tristan Plateau, one of 4 whales at $37^{\circ} 18^{\prime} \mathrm{S} 12^{\circ} 32^{\prime} \mathrm{W}$ and the other of 6 whales at $\sim 37^{\circ} 17.2^{\prime} \mathrm{S} 12^{\circ} 34.2^{\prime} \mathrm{W}$. Photographs were taken of both groups, and the size and pigmentation patterns of the whales were later used to identify them as T. shepherdi (Pitman et al., 2006). An earlier sighting (of 2 whales just off the south-west corner of Inaccessible Island on 4 November 1985) may in retrospect also have been of this species (although no photographs were taken from which confirmation might have been possible).

The only other records of Shepherd's beaked whale from the South Atlantic are a sighting near Gough Island and 7 records from Argentina (Pitman et al., 2006; Grandi et al., 2005).

\section{ANDREW'S BEAKED WHALE MESOPLODON}

BOWDOINI ANDREWS, 1908

About 10 March 1988, two beaked whales washed ashore at Cave Gulch, Tristan da Cunha. Their skeletons were preserved by J.P.G. and eventually collected by Graham Ross in October 1988. Unfortunately it seems that the two skeletons may have become mixed at some stage before they were accessioned, but the material available at the South African Museum consists of:

(ZM 40936) 7 thoracic, 6 lumbar, 5 caudal vertebrae, 1 scapula, the proximal part of one flipper, sternum (3 sections) and sundry rib fragments; 
(ZM 40937) 1 damaged skull, 2 fragmented mandibles plus teeth, 3 cervical, 10 thoracic, 13 lumbar, 6 caudal vertebrae and sundry rib fragments (Figure 8).

Both specimens were clearly juvenile, with loose epiphyses to all vertebrae and wide open pulp cavities in the teeth Morphological criteria used to identify these specimens as M. bowdoini (by a process of elimination from those ziphiids known to occur in the southern hemisphere) included:

1. Teeth situated at level of posterior of mandibular symphysisexcludes Hyperoodon, Berardius, Ziphius, Tasmacetus, Indopacetus, Mesoplodon mirus, M. hectori and M. europaeus.

2. Tooth strongly directed backwards-excludes $M$. grayi and M. ginkgodens.

3. Denticle vertical-excludes $M$. layardii.

4. Premaxillary crest exceeds $140 \mathrm{~mm}$ in length (even in such a young animal), with the right premaxillary crest not extending posteriorly beyond the right nasal-excludes $M$. densirostris, $M$. traversii and $M$. peruvianus.

The identity of these specimens as M. bowdoini was confirmed by M.L.D. through phylogenetic comparison to a reference database of mitochondrial (mt) DNA sequences (Dalebout et al., 2004, 2007). Using the silica-based method (e.g. Rohland \& Hofreiter, 2007), DNA was extracted from each specimen using approximately 0.05-0.1 gm of bone powder (ZM 40936, epiphyseal disc; ZM 40937, tooth), and several short fragments of the mtDNA control region and cytochrome $b$ genes were PCR-amplified and sequenced. At the control region (430 base pairs (bp)), ZM 40936 represents the same haplotype (i.e. same maternal lineage) as five
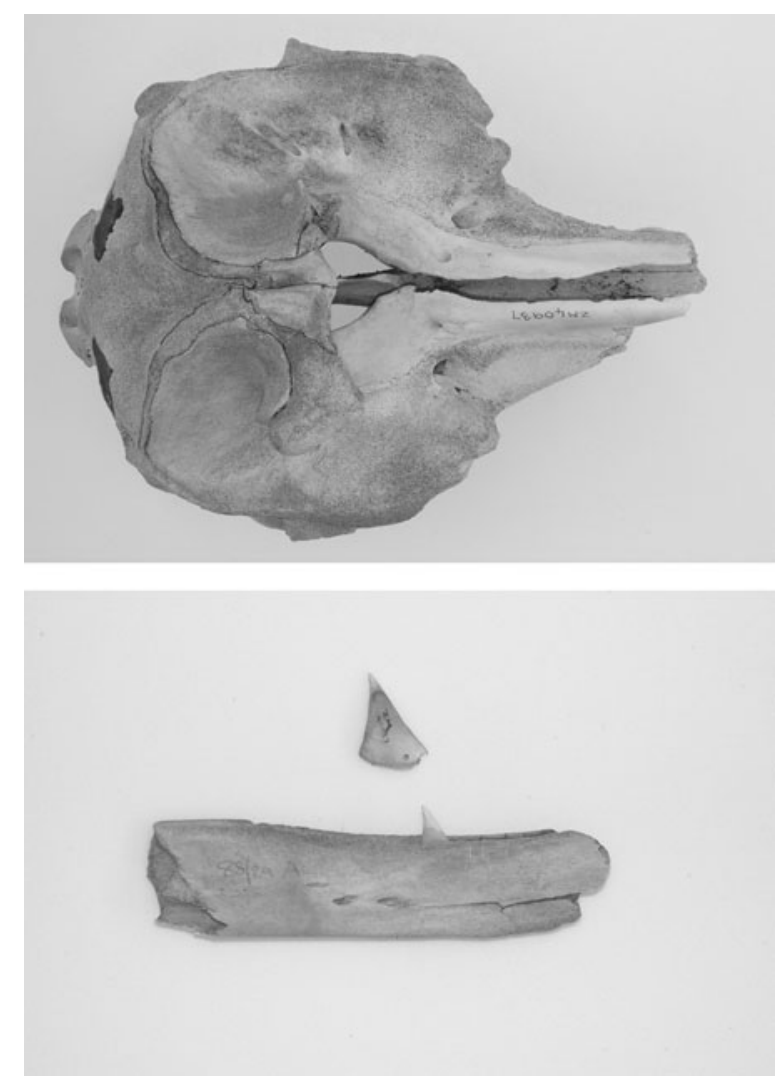

Fig. 8. Remains of skull and lower jaw of juvenile Andrew's beaked whale stranded at Tristan da Cunha in 1988.
M. bowdoini from New Zealand, one from Tasmania, and one from Western Australia. ZM 40937 represents a different haplotype which differs by 4 bp from that of ZM 40936, and which it shares with three M. bowdoini from New Zealand and two from Tasmania. At the cytochrome $b$ (270 bp), ZM 40937 represents the same haplotype as one M. bowdoini from New Zealand and one from South Australia. No cytochrome $b$ sequence data are held at present for ZM 40936.

These two records of $M$. bowdoini were previously reported by Baker (2001; specimens 34 and 35). Note however that the $\mathrm{ZM}$ specimen numbers listed in table 1 of that publication are incorrect. The only other records of Andrew's beaked whale from the South Atlantic are two individuals from strandings in the Falkland Islands (Baker, 2001) and a stranded animal from Tierra del Fuego, Argentina and one from Uruguay (Laporta et al., 2005).

\section{TRUE'S BEAKED WHALE MESOPLODON MIRUS}

TRUE, 1913

On 12 June 1993 a $4.6 \mathrm{~m}$ female beaked whale was found dead (and already decomposing) at Deadman's Bay, Stony Beach, Tristan da Cunha. The animal was dissected by J.P.G. and the incomplete skeleton later collected for the South African Museum (ZM 41261; Figure 9). Dissection revealed that it was pregnant with a $1.09 \mathrm{~m}$ female foetus. Sets of body measurements were taken of both the adult and foetus (Table 2).

The animal was distinguished as a True's beaked whale from those other ziphiids known to occur in the southern hemisphere using the following skull characteristics (Beaked Whale Identification Guide, 2007):

1. Teeth were situated in terminal alveoli (tips of mandibles damaged so exact distance back from tip of jaw uncertain)-excludes $M$. bowdoini, $M$. densirostris, M. europaeus, M. grayi, M. ginkgodens, M. layardii, $M$. peruvianus and $M$. traversii.

2. On the skull vertex the premaxillary bone extends further forward than either the nasal or frontal bones-excludes Berardius and Ziphius.

3. The space between the nasal bones on the vertex was wide and U-shaped with parallel sides, and a central groove running down the centre of the nasal bones so depressed

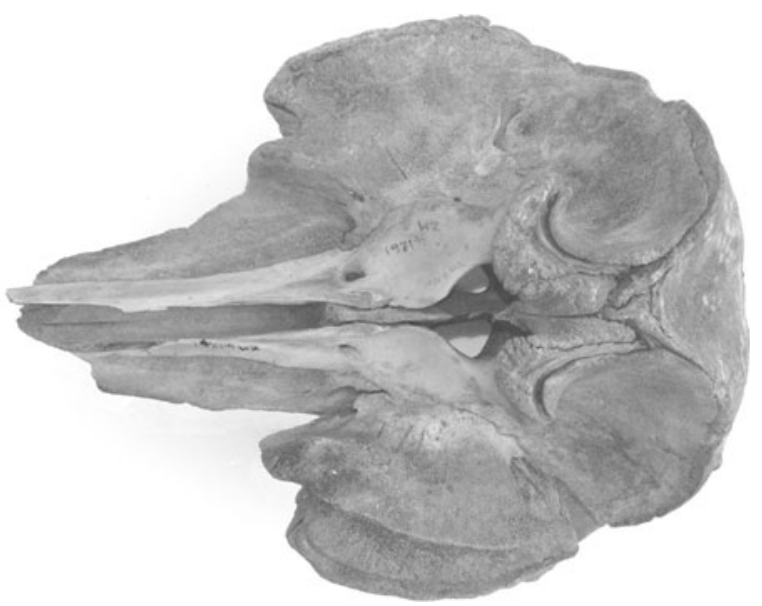

Fig. 9. Remains of skull of adult True's beaked whale stranded at Tristan da Cunha in 1993. 
Table 2. External measurements of True's beaked whale and foetus stranded at Tristan da Cunha in 1993.

\begin{tabular}{llc}
\hline Measurement (cm) & Adult & Foetus \\
\hline Total length & 460 & 109 \\
Tip of snout to apex of melon & $\sim 25$ & 7 \\
Tip of snout to blowhole & $\sim 85$ & 13 \\
Tip of snout to anterior insertion of flipper & 117 & \\
Tip of snout to anterior insertion of dorsal fin & 298 & 76 \\
Notch in flukes to centre of anus & & 37 \\
Flipper length, anterior insertion to tip & 38 & 8 \\
Flipper, maximum width & 12 & \\
Dorsal fin, vertical height & 15 & 4 \\
Width of flukes & $2 \times 59$ & 20 \\
\hline
\end{tabular}

them that it is their lateral portions that project furthest forward each side of the vertex-excludes Tasmacetus and Indopacetus.

4. Looking at the skull from in front with the long axis of the beak horizontal, a line joining the summits of the left and right maxillary prominences transected the mesethmoid bone-excludes Hyperodon.

5. The lacrymal and frontal bones comprised the apex of the antorbital tubercle-excludes $M$. hectori.

This record extends the known distribution of True's beaked whale in the South Atlantic, where it was previously only recorded from strandings on the south and west coasts of South Africa (as far north as $32^{\circ} 30^{\prime} \mathrm{S}$-South African Museum records) and a single record from Brazil, at $23^{\circ} 46^{\prime} \mathrm{s}$ (De Souza et al., 2005).

\section{UNIDENTIFIED BEAKED WHALES}

Although it was impossible to make specific identifications, the following sightings of 'beaked whales' have been included because of their general rarity and to show that the area may be one of special importance to these animals.

On 10 January 2000 a pod of $3-6$ beaked whales was seen from the top of Inaccessible Island on a calm day with good visibility. They were about 1 nautical mile off West Point, and appeared all dark with a prominent beak and largish dorsal fin far back on the body. They lolled on the surface for about 5 minutes and then dived and were not seen again.

On 10 February 2000 a pod of $6-10$ beaked whales was seen $\sim 5$ nautical miles north of Nightingale Island. They were lolling at the surface and were as little as $50 \mathrm{~m}$ from the boat at one time. They were estimated at 5-10 $\mathrm{m}$ long and resembled those seen a month earlier, although a paler saddle behind the dorsal fin was visible on some animals.

On 28 August 1990 four medium-sized whales were seen about 0.4 nautical mile off the Settlement, in a light swell. According to the observer (D.J. Sorensen-Pound) they most closely resembled southern bottlenose whales, with a definite snout breaking the water ahead of a prominent melon. The flukes were never exposed.

\section{Family Delphinidae}

\section{ROUGH-TOOTHED DOLPHIN STENO BREDANENSIS}

\section{(G. CUVIER IN LESSON, 1828)}

Although 'Tristan da Cunha' has sometimes been included in the published distribution of this species (Watson, 1981), this seems to be based on the specimen collected in September 1874 at the position $32^{\circ} 29^{\prime} \mathrm{S} 2^{\circ} 0.7^{\prime} \mathrm{W}$, or some $1068 \mathrm{~km}$ north-east from Tristan da Cunha (Peters, 1876). There are no documented records closer to the archipelago, and it seems unlikely that the species occurs there regularly, if at all.

\section{COMMON DOLPHIN DELPHINUS SP. (LIKELY}

\section{DELPHIS, SHORT-BEAKED COMMON DOLPHIN)}

On 7 October 1988, 90 common dolphins were seen from MV 'Agulhas' at $36^{\circ} 18.6^{\prime} \mathrm{S} 8^{\circ} 53.5^{\prime} \mathrm{W}$, or about $315 \mathrm{~km}$ eastnorth-east from Tristan da Cunha. Although the species was given as delphis, the sighting pre-dated the publication by Heyning \& Perrin (1994) that documented the morphological differences between long-beaked common dolphins $D$. capensis and short-beaked common dolphins D. delphis, so it is unclear whether the observer (G.J.B. Ross) was following the convention of a single common dolphin species, $D$. delphis or not. Notes and a sketch indicate that the thoracic patch was noticeably yellow-brown, 'resembling the bright colours used in Lyall Watson's book [Watson, 1981]'. As a relatively lighter thoracic patch is one of the characters discriminating short-beaked from long-beaked common dolphins (including off South Africa; Samaai et al., 2005), it is possible that these were indeed $D$. delphis rather than D. capensis (as one would expect from the more oceanic distribution of shortbeaked common dolphins in the subregion; Best, 2007). Bester \& Ryan (2007) reported that common dolphins are rare at Tristan but are more common in oceanic waters.

Tristan da Cunha has been included in the distribution of D. delphis by Tomilin (1957) and Hershkovitz (1966). This claim seems to have originated from the statement of True (1889) that specimens representing two new species of Delphinus described by Gray (1865) as D. Moorei and D. Walkeri (subsequently subsumed into D. delphis) were 'from a point in the South Atlantic, in the vicinity of Tristan da Cunha'. However, the two specimens on which these species descriptions were based were collected at $34^{\circ} \mathrm{S}$ $7^{\circ} 3^{\prime} \mathrm{W}$ and $35^{\circ} 38^{\prime} \mathrm{S} 10^{\circ} \mathrm{E}$, or $585 \mathrm{~km}$ north-east and nearly $2000 \mathrm{~km}$ east of Tristan, respectively.

\section{DUSKY DOLPHIN LAGENORHYNCHUS OBSCURUS}

(GRAY, 1828)

Bester \& Ryan (2007) list this species as 'probably resident in waters around Tristan and Gough'. However, while there are a number of substantiated records of the species at Gough Island (Van Waerenbeek et al., 1995), reported sightings at Tristan da Cunha are much rarer, and none is substantiated by photographs or a stranding.

\section{SOUTHERN RIGHT WHALE DOLPHIN}

LISSODELPHIS PERONII (LACÉPÈDE, 1804)

On 10 December 1847 the capture of a southern right whale dolphin was recorded in the logbook of the whaling vessel 'Samuel and Thomas', with the noon position of the vessel being given as $37^{\circ} 03^{\prime} \mathrm{S} 11^{\circ} 36^{\prime} \mathrm{W}$ (Cruickshank \& Brown, 1981). This is some $60 \mathrm{~km}$ east of Tristan da Cunha. There are no recent sightings of this distinctive animal from Tristan waters.

KILLER WHALE ORCINUS ORCA (LINNAEUS, 1758)

On 27 September 1987, a group of 4 killer whales was seen from MV 'SA Agulhas' 10 nautical miles off the east coast 
of Tristan da Cunha. The next day, a group of 5 killer whales was seen from the air about $800 \mathrm{~m}$ off the east end of Sandy Point, Tristan da Cunha. On 17 October 1989, two killer whales were reported $\sim 365 \mathrm{~m}$ (400 yards) off the harbour at Tristan da Cunha (D.J. Sorensen-Pound, in litt. 16 October 1990).

Pitman \& Ensor (2003) described three morphotypes of killer whales from the Antarctic, distinguished on the basis of size, coloration and schooling behaviour. It is not known which morphotype occurs at Tristan da Cunha.

Shortly after Tristan da Cunha was first inhabited, it was reported that 'During the [elephant seal] Pupping Season the Black Fish are very numerous and equally rapacious, always on the look out for the Elephants great or small. I have seen them attack young or old ones, and carry young ones off. They run themselves aground on the Beach very often, so that we lance them frequently and shoot into them (Jonathan Lambert to Captain J Briggs, 21 December 1811Lockerby, 1925). There seems little doubt that the 'Black Fish' were killer whales, and their behaviour resembles that reported for the coast of Argentina (Hoelzel, 1991) and the Crozet Islands (Guinet, 1992). As the elephant seal population at Tristan has been at low levels since it was hunted intensively from the late 18th to early 19th Centuries (Bester \& Ryan, 2007), the killer whales that used to prey on them have presumably had to adopt new feeding strategies (if they survived the attempts to kill them).

\section{LONG-FINNED PILOT WHALE GLOBICEPHALA}

MELAS (TRAILL, 1809)

On 15 February 1990 a small cetacean was found in an advanced state of decay at Blenden Hall Bay (1 km north-east of West Point), Inaccessible Island, and some skull fragments were collected and presented to the South African Museum (ZM 41644). From the relatively large alveoli confined to the front half of the rostrum (and the unfused nature of the skull fragments), the specimen was identified as a juvenile pilot whale Globicephala sp.

On 23 October 1990 a $1.98 \mathrm{~m}$ pilot whale was found dead and partly decomposing at Big Point, Tristan da Cunha: its sex was uncertain but recorded as possibly male. The head was later collected by J.P.G. and buried: the skull was eventually presented to the South African Museum (ZM 41117). After cleaning, the skull was identified from the presence of 9-10 alveoli in the lower jaw, the upper tooth row confined to the anterior half of the rostrum, and the exposure of the maxillae either side of the premaxillae in the distal portion of the rostrum, as that of a long-finned pilot whale, G. melas. The unfused nature of the fragments indicated that this, too, was a juvenile.

A shore-based observer at Tristan da Cunha reported 'I have seen quite a number of fairly nondescript, dark, medium-sized whales which I am sure were Globicephalidae.

Table 3. Sightings of globicephalids from Tristan da Cunha, 1990.

\begin{tabular}{lll}
\hline Date & Locality & Number \\
\hline 23 February 1990 & Off Edinburgh & $6-8$ \\
29 March 1990 & Off Hottentot Point & $6+20-30$ 'dolphins' \\
21 August 1990 & Off volcano & 6 \\
28 August 1990 & Off Edinburgh & 6 \\
\hline
\end{tabular}

They showed none of the characteristics of false killer whales, the term applied to most whales on Tristan which are not Right whales or dolphins. I am pretty sure that they were one or other of the Pilot whales, probably Long-fin by their behaviour' (D.J. Sorensen-Pound, in litt. 16 October 1990). Details of the sightings are given in Table 3.

On 19 February 2000, a pod of pilot whales (possibly longfinned) accompanied by some small fast dolphins with deeply falcate dorsal fins was encountered 4 miles off Tristan da Cunha, while the MV 'Tristania' was en route to Cape Town.

There is no evidence that these sightings were of shortfinned pilot whales G. macrorhynchus, although the distribution of this species in the South Atlantic is poorly known (Best, 2007).

\section{DISCUSSIDN}

In total, five species of cetaceans (southern right whale, humpback whale, Shepherd's beaked whale, long-finned pilot whale and killer whale) have been sighted within the territorial waters (12 mile limit) of the Tristan da Cunha archipelago, and another eight species (fin whale, sei whale, minke whale, sperm whale, True's beaked whale, Andrew's beaked whale, common dolphin and southern right whale dolphin) have either been sighted or taken within 200 nautical miles or stranded on the shores of this isolated island group. Two further species (pygmy right whale and dusky dolphin) have been recorded at sea close enough to Tristan da Cunha to be considered likely to occur within 200 nautical miles. The area has not been thoroughly surveyed, however, and the list of cetacean species occurring within 200 nautical miles of the island group is likely to be larger than that given here.

Citations in the literature to the occurrence of the roughtoothed dolphin at Tristan seem to refer to an historical record over $1000 \mathrm{~km}$ to the north-east, and the species is deemed unlikely to occur in the region.

Most of the 19th-Century catches of southern right whales on the Tristan ground were made from late spring into summer (October through to January), and all the illegal 2oth Century catches by Soviet whalers occurred in November (Tormosov et al., 1998). As this is somewhat later than the peak calving season (Best, 1994), it seems likely that these takes indicate the presence of a pelagic feeding ground or grounds, some of the occupants of which may have over-wintered in coastal waters of the adjacent continents. Indeed some right whales satellite-tagged in the coastal waters of South Africa in September 2001 made their way as far west as $37-40^{\circ} \mathrm{S}$ $0-3^{\circ} \mathrm{E}$ by December (Mate et al., submitted).

However the high incidence of cow-calf pairs in sightings at the Tristan Archipelago (and more specifically at the main island of Tristan itself) seems to indicate that this ground includes a mid-oceanic nursery area for southern right whales. The lack of sightings at the other two islands in the group may reflect their smaller size (the coastline of Tristan da Cunha being roughly twice as long as those of Inaccessible and Nightingale combined). It may also be a consequence of the sharper drop-off in the littoral zone (especially at Nightingale) than at the main island, and the presence of some sandy beaches at Tristan but not at the other two islands (Andrew et al., 1995). Right whales (and particularly cow-calf pairs) in the coastal waters off South Africa prefer bays with gently sloping sea floors that are at least partly 
sheltered from prevailing winds and swell (Elwen \& Best, $2004 a, b)$. The concentration of cow-calf pairs in the southeast quadrant of Tristan is at least partly consistent with this pattern, in that the general angle of the coastline (and particularly the influence of Stonyhill Point at the southern tip of the island) would provide some protection from westerly swells. The potential number of females using such a calving/ nursery area, however, cannot be very great: the combined coastline of all three islands in the group only amounts to some $60 \mathrm{~km}$. This compares to over $600 \mathrm{~km}$ of coastline utilized by wintering right whales on the South African coast, for example (Elwen \& Best, 2004a).

A review of 19th Century whaling logbooks might indicate whether or not cow-calf pairs constituted a significant part of the right whale catch at the archipelago, thus addressing the question of whether this was also a nursery ground historically. According to Elliott (1953), small calves were 'fairly frequent' at the island group in the early 1950 .

Given that the Tristan Archipelago is believed to be located at the northern boundary of the Sub-Tropical Convergence, the apparent failure of small males and female sperm whales to feature in catches south of about $37^{\circ} 30^{\prime} \mathrm{S}$ in the Tristan Square would be consistent with the hypothesis that the southern limit to their distribution in the southern hemisphere as a whole is in some way correlated with the position of the Sub-Tropical Convergence (Best, 1979).

Shepherd's beaked whale is one of the poorest known of the medium - large cetaceans, being represented by only 42 strandings (24 of which have been in the New Zealand region) and 5 possible and 4 probable sightings (Pitman et al., 2006). Six $(14 \%)$ of these strandings and two $(50 \%)$ of the probable sightings have occurred in the Tristan Archipelago, making it one of the few places in the world where this species might reliably be sighted. Too little is known of the species' biology to determine why it might be attracted to the archipelago. The presence of numerous erupted teeth in both jaws of adults of both sexes (so far undescribed for any other beaked whale species) has led to speculation that the species is primarily a fish-eater in contrast to most other species in this family which appear to prey largely on deep water cephalopods (e.g. MacLeod et al., 2003). However, the single stomach examined at Tristan contained only cephalopod remains (Pitman et al., 2006). Possibly the plateau on which the three islands are based bears some similarity to sea mounts elsewhere that have been shown to be associated with increased productivity (Rogers, 1994). However, it is equally possible that the whales are attracted to some bathymetric characteristics of the inter-island trenches, similar to the situation for northern bottlenose whales at a canyon (the Gully) off Nova Scotia, Canada. Here the whales congregate over deep water $(500-1500 \mathrm{~m})$ and particularly where the bottom topography is steep, and are principally found in an area of about $30 \mathrm{~km} \times 10 \mathrm{~km}$ where they forage intensively, with inter-annual variations in distribution occurring mainly along the long axis of the canyon (Hooker et al., 2002). Future investigations of the identity, distribution and behaviour of the beaked whales occurring at the Tristan plateau would seem to be well justified.

\section{ACKNOWLEDGEMENTS}

Shipboard and aerial observations were undertaken by K.P. Findlay, M.A. Meÿer, D.A. Ohland, V.M. Peddemors and G.J.B. Ross, and land-based observations by D.J. Sorensen-Pound, to all of whom we are greatly indebted. Participation in Voyages \#32, 42, 46, 51, 55 and 59 of MV 'SA Agulhas', including use of the ship-based Puma helicopter, was undertaken with the permission of the Department of Environment Affairs and as part of the South African National Antarctic Research Programme. The cooperation of Captain W.M. Leith, officers and crew of the SA 'Agulhas', and the pilots, flight and ground crew of 30 Squadron, South African Air Force, was essential for the success of the surveys at Tristan da Cunha. Particulars and photographs of the 1983 Shepherd's beaked whales were kindly provided by M.K. Swales, formerly of Denstone College, UK. Special thanks are due to Cherry Allison of the International Whaling Commission, for the extraction of catches of large whales in the Tristan Square from the IWC's Catch Record Data Base.

\section{REFERENCES}

Andrew T.G., Hecht T., Heemstra P.C. and Lutjeharms J.R.E. (1995) Fishes of the Tristan da Cunha group and Gough Island, South Atlantic Ocean. Ichthyological Bulletin of the J. L. B. Smith Institute of Ichthyology, Grahamstown, South Africa 63, 1-43.

Baker A.N. (2001) Status, relationships, and distribution of Mesoplodon bowdoini Andrews, 1908 (Cetacea: Ziphiidae). Marine Mammal Science 17, 473-493

Beaked Whale Identification Guide (2007) See Smithsonian Institution website http://vertebrates.si.edu/mammals/beaked_whales/pages/.

Best P.B. (1979) Social organisation in sperm whales, Physeter macrocephalus. In Winn H.E. and Olla B.L. (eds) Behavior of marine animals. Current perspectives in research. 3. Cetaceans. New York and London: Plenum Press, pp. 227-289.

Best P.B. (1988) Right whales (Eubalaena australis) at Tristan da Cunha-a clue to the 'non-recovery' of depleted stocks? Biological Conservation 46, 23-51.

Best P.B. (1994) Seasonality of reproduction and the length of gestation in southern right whales Eubalaena australis. Journal of Zoology, London $232,175-189$.

Best P.B. (2007) Whales and dolphins of the southern African subregion. Cape Town: Cambridge University Press.

Best P.B., Schaeff C.M., Reeb D. and Palsbøll P. (2003) Composition and possible function of social groupings of southern right whales in South African waters. Behaviour 140, 1469-1494.

Bester M.N. and Ryan P.G. (2007) Mammals. In Ryan P.G. (ed.) Field guide to the animals and plants of Tristan da Cunha and Gough Island. Newbury: Pisces Publications for the Tristan Island Government, pp. 98-109.

Brown S.G. (1977) Some results of sei whale marking in the Southern Hemisphere. Report of the International Whaling Commission (Special Issue 1), 39-43.

Budylenko G.A., Panfilov B.G., Pakhomova A.A. and Sazhinov E.G. (1973) New data on pygmy right whales Neobalaena marginata (Gray, 1848). Trudy̆ Atlanticheskii Nauchno-Issledovatel'skiü Institut Ry̆bnogo Khozyaĭstva $\breve{i}$ Okeanografii, Kaliningrad 51, 122-132. [In Russian.]

Clark A.H. (1887) 1.-History and present condition of the fishery. In The Fisheries and Fishery Industries of the United States. Section V. History and methods of the fisheries. Volume II. Part XV. The whale fishery. Washington: Government Printing Office, pp. 3-218. 
Crawford A. (1982) Tristan da Cunha and the roaring forties. Cape Town David Philip.

Cruickshank R.A. and Brown S.G. (1981) Recent observations and some historical records of southern right-whale dolphins Lissodelphis peronii. Fisheries Bulletin, South Africa 15, 109-121.

Dalebout M.L., Baker C.S., Cockcroft V.G., Mead J.G. and Yamada T.K. (2004) A comprehensive and validated molecular taxonomy of beaked whales, family Ziphiidae. Journal of Heredity 95, 459-473.

Dalebout M.L., Baker C.S., Steel D., Robertson K.M., Chivers S.J., Perrin W.F., Mead J.G., Grace R.V. and Schofield D. (2007) A divergent mtDNA lineage among Mesoplodon beaked whales: molecular evidence for a new whale in the Tropical Pacific? Marine Mammal Science 23, 954-966.

De Souza S.P., Siciliano S., Cuenca S. and de Sanctis B. (2005) A True's beaked whale (Mesoplodon mirus) on the coast of Brazil: adding a new beaked whale species to the western tropical Atlantic and South America. Latin American Journal of Aquatic Mammals 4, 129-136.

Elliott H.F.I. (1953) The fauna of Tristan da Cunha. Oryx 2, 41-53

Elwen S. and Best P.B. (2004a) Environmental factors influencing the distribution of southern right whales (Eubalaena australis) on the South Coast of South Africa I: Broad scale patterns. Marine Mammal Science $20,567-582$.

Elwen S. and Best P.B. (2004b) Environmental factors influencing the distribution of southern right whales (Eubalaena australis) on the South Coast of South Africa II: Within bay distribution. Marine Mammal Science 20, 583-601.

Grandi M.F., Buren A.D., Crespo E.A., García N.A., Svendsen G.M. and Dans S.L. (2005) Record of a specimen of Shepherd's beaked whale (Tasmacetus shepherdi) from the coast of Santa Cruz, Argentina, with notes on age determination. Latin American Journal of Aquatic Mammals 4, 97-100.

Gray J.E. (1865) Description of three species of dolphins in the Free Museum at Liverpool. Proceedings of the Zoological Society of London 1865, 735-739.

Guinet C. (1992) Comportement de chasse des orques (Orcinus orca) autour des îles Crozet. Canadian Journal of Zoology 70, 1656-1667.

Hershkovitz P. (1966) Catalog of living whales. Bulletin of the United States National Museum 246, 1-259.

Heyning J.E. and Perrin W.F. (1994) Evidence for two species of common dolphins (genus Delphinus) from the Eastern North Pacific. Contributions in Science 442, 1-35.

Hoelzel A.R. (1991) Killer whale predation on marine mammals at Punta Norte, Argentina: food-sharing, provisioning and foraging strategy. Behavioral Ecology and Sociobiology 29, 197-204.

Hooker S.K., Whitehead H., Gowans S. and Baird R.W. (2002) Fluctuations in distribution and patterns of individual range use of northern bottlenose whales. Marine Ecology Progress Series 225, 287-297.

Laporta P., Praderi R., Little V. and Le Bas A. (2005) An Andrew's beaked whale Mesoplodon bowdoini (Cetacea, Ziphiidae) stranded on the Atlantic coast of Uruguay. Latin American Journal of Aquatic Mammals 4, 101-111.
Lockerby W. (1925) In Im Thurm E. and Wharton L.C. (eds) The journal of William Lockerby sandalwood trader in the Fijian islands during the years 1808-1809. London: The Hakluyt Society, second series 52.

MacLeod C.D., Santos M.B. and Pierce G.J. (2003) Review of data on diets of beaked whales: evidence of niche separation and geographic segregation. Journal of the Marine Biological Association of the United Kingdom 83, 651-665.

Peters W. (1876) S.M.S. Gazelle gesammelten Säugethiere aus den Abtheilungen der Nager, Hufthiere, Sirenen, Cetaceen und Beutelthiere. Monatsberichte der K. Akademie der Wissenschaften zu Berlin 1876, 355-366+3 pl.

Pitman R.L. and Ensor P. (2003) Three forms of killer whales (Orcinus orca) in Antarctic waters. Journal of Cetacean Research and Management 5, 131-139.

Pitman R.L., Van Helden A.L., Best P.B. and Pym A. (2006) Shepherd's beaked whale (Tasmacetus shepherdi): information on appearance and biology based on strandings and at-sea observations. Marine Mammal Science 22, 744-755.

Rogers A.D. (1994) The biology of seamounts. In Blaxter J.H.S. and Southward A.J. (eds) Advances in marine biology 30. London, San Diego, New York, Boston, Sydney, Tokyo and Toronto: Academic Press, pp. 305-350.

Rohland N. and Hofreiter M. (2007) Comparison and optimization of ancient DNA extraction. BioTechniques 42, 343-352.

Samaai T., Best P.B. and Gibbons M.J. (2005) The taxonomic status of common dolphins Delphinus spp. in South African waters. African Journal of Marine Science 27, 449-458.

Tomilin A.G. (1957) Cetacea. In Heptner V.G. (ed.) Mammals of the USSR and adjacent countries, 9. Moscow: Akademi Nauk SSSR. [Translated by Israel Program for Scientific Translations, 1967]

Tormosov D.D., Mikhaliev Y.A., Best P.B., Zemsky V.A., Sekiguchi K. and Brownell R.L. Jr (1998) Soviet catches of southern right whales, Eubalaena australis, 1951-1971; biological data and conservation implications. Biological Conservation 86, 185-197.

Townsend C.H. (1935) The distribution of certain whales as shown by logbook records of American whaleships. Zoologica, New York 19, $1-50$.

True F.W. (1889) Contributions to the natural history of the cetaceans, a review of the family Delphinidae. Bulletin of the United States National Museum 36, 1-191 + $47 \mathrm{pl}$.

Van Waerenbeek K., van Bree P.J.H. and Best P.B. (1995) On the identity of Prodelphinus petersii Lutken, 1889 and records of dusky dolphins Lagenorhynchus obscurus (Gray, 1828) from the southern Indian and Atlantic Oceans. South African Journal of Marine Science $16,25-35$

and

Watson L. (1981) Sea guide to whales of the world. New York: E.P. Dutton.

\section{Correspondence should be addressed to:}

P.B. Best

Mammal Research Institute

University of Pretoria, South Africa

email: pbest@iziko.org.za 